\title{
2 Implementasi Kebijakan Keterbukaan Informasi Publik dalam Mewujudkan Desa Informatif di Kabupaten Bangka (Studi di Desa Bukit Layang Kecamatan Bakam)
}

\author{
Syahrezi Fajar \\ syahrezifajar@gmail.com \\ STISIPOL Pahlawan 12 Sungailiat
}

\section{ABSTRAK}

Penelitian ini dilakukan untuk melihat implementasi kebijakan keterbukaan informasi publik dalam mewujudkan desa informatif di Kabupaten Bangka (Studi di Desa Bukit Layang Kecamatan Bakam). Jenis penelitian yang digunakan adalah penelitian kualitatif, khususnya kualitatif interaktif, yakni penelitian yang menuntut penulis berinteraksi langsung dengan objek penelitian. Teknik pengumpulan data dilakukan melalui wawancara, observasi (pengamatan), dan studi kepustakaan. Hasil penelitian menunjukkan bahwa variabel komunikasi belum berjalan baik. Adapun untuk variabel sumber daya cukup baik. Begitu pula dengan variabel disposisi yang sudah berjalan cukup baik. Untuk variabel terakhir, yakni struktur birokrasi, diimplementasikan dengan cukup baik.

Kata kunci: implementasi, keterbukaan informasi publik, Desa Bukit Layang

\section{ABSTRACT}

This research was conducted to see the implementation of public information disclosure policy in realizing informative villages in Bangka Regency (Study in Bukit Layang Village, Bakam District). This type of research used in this study is qualitative research, especially interactive qualitative where this study requires writers to interact directly with the object of research. Data collection techniques were carried out through interviews, observations, and literature studies. The results showed that the communication variable had not gone well. Furthermore, for the resource variable, it is quite good. Likewise, the disposition variable has gone quite well. As for the last variable, the bureaucratic structure is implemented quite well.

Keywords: implementation; openness of public information; Bukit Layang village 


\section{PENDAHULUAN}

Informasi merupakan manifestasi kebutuhan setiap orang tanpa terkecuali, yang telah bertransformasi menjadi suatu hak yang harus terpenuhi. Hak memperoleh informasi juga merupakan perwujudan hak asasi manusia dan diatur secara khusus dalam Undang-Undang Dasar 1945 Pasal 28F yang berbunyi "Setiap orang berhak untuk berkomunikasi dan memperoleh informasi untuk mengembangkan pribadi dan lingkungan sosialnya, serta berhak untuk mencari, memperoleh, memiliki, menyimpan, mengolah, dan menyampaikan informasi dengan menggunakan segala jenis saluran yang tersedia." Pasal inilah yang kemudian menjadi salah satu inisiasi pembentukan regulasi keterbukaan informasi publik.

Keterbukaan informasi publik secara yuridis telah termaktub dalam peraturan perundangundangan, yakni dalam Undang-Undang Republik Indonesia Nomor 14 Tahun 2008 tentang Keterbukaan Informasi Publik.

Keterbukaan informasi publik memang sudah seharusnya diimplementasikan secara optimal oleh segenap badan publik yang tugas pokok dan fungsinya berkaitan erat dengan penyelenggaraan negara, yang seluruh atau sebagian dananya bersumber dari APBN/APBD, termasuk dalam hal ini desa.

Berdasarkan Peraturan Komisi Informasi Nomor 1 Tahun 2018 tentang Standar Layanan Informasi Publik Desa pasal 1 angka 3, dinyatakan bahwa "Badan Publik Desa adalah Pemerintah Desa, Badan Permusyawaratan Desa, Badan Usaha Milik Desa, dan Badan Kerjasama Antar Desa." Dalam hal ini, Pemerintah Desa dan Badan
Permusyawaratan Desa Bukit Layang yang menjadi fokus penelitian ini merupakan badan publik desa yang memiliki kewajiban dalam menyediakan dan memberikan informasi publik kepada masyarakat desa.

Observasi penulis di lapangan menunjukkan bahwa desa ini-hingga tulisan ini dibuatbelumlah memiliki Pejabat Pengelola Informasi dan Dokumentasi (PPID) desa. Selain itu, peraturan desa mengenai keterbukaan informasi publik juga belum pernah dibuat di Desa Bukit Layang. Padahal, jika menilik Peraturan Komisi Informasi Nomor 1 Tahun 2018 tentang Standar Layanan Informasi Desa pasal 7 angka (a), dijelaskan bahwa "Pemerintah Desa wajib menetapkan Peraturan Desa mengenai Keterbukaan Informasi Publik."

\section{LANDASAN TEORI Implementasi}

Implementasi dan kebijakan merupakan dua hal yang tidak dapat dipisahkan. Dalam hal ini, implementasi dapat diartikan sebagai suatu penerapan atau pelaksanaan kebijakan yang dibuat oleh pemerintah. Kebijakan pemerintah, baik berupa program maupun regulasi (yang notabene telah terencanakan), perlu diimplementasikan agar dapat berdampak kepada kelompok sasaran. Hal ini sejalan dengan pendapat yang dikemukakan Purwanto dan Sulistyastuti (2015: 21) bahwa "implementasi intinya adalah kegiatan untuk mendistribusikan keluaran kebijakan (to deliver policy output) yang dilakukan oleh para implementer kepada kelompok sasaran (target group) sebagai upaya untuk mewujudkan tujuan kebijakan."

Sementara itu, Mazmanian dan Sabatier 
(dalam Wahab, 2017: 135) menjelaskan bahwa implementasi adalah memahami apa yang senyatanya terjadi sesudah suatu program dinyatakan berlaku atau dirumuskan, yang menjadi fokus perhatian implementasi kebijaksanaan, berupa kejadian-kejadian dan kegiatan-kegiatan yang timbul sesudah disahkannya pedomanpedoman kebijaksanaan negara serta menimbulkan akibat/dampak nyata pada masyarakat.

Tahapan implementasi kebijakan merupakan bagian yang terpenting dalam proses kebijakan sebagaimana yang dikemukakan oleh Udoji (dalam Wahab, 2017: 126) yang mengatakan bahwa "the execution of policies is important if not more important than policymaking. Policies will remain dreams or print in file jackets unless they are implemented" (pelaksanaan kebijakan merupakan hal penting yang mungkin jauh lebih penting daripada pembuatan kebijakan. Kebijakankebijakan hanya akan berupa impian jika tidak diimplementasikan).

Hal senada juga turut disampaikan Adiwisastra (dalam Tahir, 2015: 54) yang mengatakan bahwa "implementasi merupakan sesuatu yang penting. Kebijakan publik yang dibuat hanya akan menjadi 'macan kertas' apabila tidak berhasil dilaksanakan."

Edward III (dalam Tahir, 2015: 61) mengatakan bahwa di dalam studi implementasi kebijakan pertanyaan abstraknya dimulai dari bagaimana prakondisi untuk suksesnya sebuah implementasi kebijakan, dan kedua adalah apa hambatan utama dari kesuksesan implementasi kebijakan. Untuk menjawab pertanyaan tersebut, Edward III (dalam Mulyadi, 2016: 68) mengemukakan empat variabel yang mempengaruhi implementasi kebijakan, yakni sebagai berikut:

1. Komunikasi

Implementor harus mengetahui dengan jelas terkait dengan apa yang harus dilakukan. Tujuan dan sasaran kebijakan harus ditransmisikan secara jelas dan konsisten kepada kelompok target (target group) untuk menghindari distorsi implementasi kebijakan.

2. Sumber daya

Meski isi kebijakan telah dikomunikasikan secara jelas, jika implementor kekurangan sumber daya untuk melaksanakan implementasi tersebut, maka implementasi kebijakan tidak akan berjalan efektif. Sumber daya meliputi sumber daya manusia, kompetensi implementor, dan sumber daya finansial.

3. Disposisi

Disposisi adalah watak dan karakteristik yang dimiliki implementor, seperti komitmen, kejujuran, dan sifat demokratis.

\section{Struktur birokrasi}

Salah satu aspek yang penting dari struktur birokrasi adalah adanya Standard Operating Procedures (SOP). SOP akan menjadi pedoman bagi implementor dalam bertindak.

\section{Keterbukaan Informasi Publik}

Di Indonesia keterbukaan informasi publik mulai menjadi perhatian sejak diberlakukannya Undang-Undang Nomor 14 Tahun 2008 tentang Keterbukaan Informasi Publik. Dalam regulasi ini, dijelaskan bahwa informasi publik adalah informasi yang dihasilkan, disimpan, dikelola, dikirim, dan/atau diterima oleh suatu badan publik yang berkaitan dengan penyelenggara dan penyelenggaraan negara dan/atau penyelenggara 
dan penyelenggaraan badan publik lainnya sesuai dengan undang-undang ini serta informasi lain yang berkaitan dengan kepentingan publik.

\section{METODOLOGI}

Penelitian ini menggunakan penelitian kualitatif. Sugiyono (2017: 8) berpendapat bahwa penelitian kualitatif memandang realitas sosial sebagai sesuatu yang holistik/utuh, kompleks, dinamis, penuh makna, dan hubungan gejala bersifat interaktif (reciprocal).

Penelitian ini dilakukan di Desa Bukit Layang Kecamatan Bakam Kabupaten Bangka. Sumber data yang digunakan dalam penelitian ini diperoleh melalui dua sumber, yakni sumber data primer dan sumber data sekunder. Data primer adalah data yang diperoleh langsung dari subjek penelitian, sedangkan data penunjang yang berkaitan dengan pokok pembahasan dalam penelitian sifatnya melengkapi dan memperkuat data primer.

Teknik pengumpulan data dalam penelitian ini menggunakan wawancara, observasi, dan studi kepustakaan.

Analisis data yang digunakan antara lain: reduksi data, penyajian data, dan penarikan kesimpulan, dan verifikasi.

\section{HASIL DAN PEMBAHASAN}

Desa Bukit Layang merupakan salah satu desa di Kecamatan Bakam Kabupaten Bangka mempunyai luas wilayah 25.281,90 ha dengan batas-batas administrasi sebagai berikut: sebelah utara berbatasan dengan Desa Penyamun; sebelah selatan berbatasan dengan Desa Mabat; sebelah barat berbatasan dengan Desa Berbura, Desa Pugul,
Desa Cit; sebelah timur berbatasan dengan Desa Air Duren.

1. Komunikasi

Jika diurutkan dari pernyataan Syawaludin, M.H. (Ketua Komisi Informasi Provinsi Kepulauan Bangka Belitung) yang menyatakan bahwa sosialisasi tentang keterbukaan informasi publik desa baru sekali dilakukan, yakni pada tahun 2019, yang saat itu difasilitasi Dinas Komunikasi, Informatika, dan Statistik Kabupaten Bangka. Tentu saja hal ini masih belum cukup untuk mengawal keterbukaan informasi publik di desa. Apalagi jika menilik pernyataan Ketua Komisi Informasi Provinsi Kepulauan Bangka Belitung-bahwa sosialisasi belum sampai pada tahap teknis - maka kendala pemerintah desa dalam mewujudkan keterbukaan informasi publik di tempatnya belumlah teratasi.

Berdasarkan wawancara dengan M. Khadafi, S.Sos. (Kepala Seksi Informasi Publik Dinas Komunikasi, Informatika dan Statistik Kabupaten Bangka) diperoleh keterangan bahwa pemerintah daerah kabupaten sudah memberikan dua kali sosialisasi terkait keterbukaan informasi publik desa. Menurut penulis, capaian ini juga masih jauh dari kata ideal untuk menuntut badan publik desa mampu melaksanakan kebijakan keterbukaan informasi. Di lain pihak, pemerintah desa sebenarnya sudah cukup memahami bahwa desa memang harus terbuka dan transparan. Akan tetapi, minimnya sosialisasi yang diberikan akan berpengaruh terhadap pemahaman pihak desa dalam melaksanakan kebijakan keterbukaan informasi publik.

Berikutnya kita alihkan ke lingkup yang lebih sempit, yakni Desa Bukit Layang yang menjadi 
fokus penelitian ini. Berdasarkan observasi dan hasil wawancara penulis kepada Kepala Desa, Sekretaris Desa, Ketua BPD, Kepala Dusun, dan SMD menyatakan bentuk keterbukaan informasi publik yang disampaikan pemerintah desa kepada masyarakat desa umumnya hanya dilakukan dengan cara memasang baliho/spanduk/banner APBDes di tiap dusun.

Aktivitas tersebut dirasakan belum cukup efektif bagi beberapa masyarakat dalam upaya mewujudkan desa informatif. Jika menelaah pernyataan beberapa masyarakat yang menjadi narasumber penelitian ini, mereka menyatakan bahwa pada dasarnya masyarakat desa juga menginginkan cara atau pendekatan yang lain sebagai bentuk keterbukaan informasi yang dilakukan pihak desa. Cara atau pendekatan yang lain itu tidak lain adalah upaya-upaya menginformasikan segala sesuatu yang menjadi hak masyarakat untuk tahu.

\section{Sumber Daya}

Masih ada beberapa kendala yang dihadapi dalam pelaksanaan kebijakan keterbukaan informasi publik. Sebagai contoh, Komisi Informasi Provinsi Kepulauan Bangka Belitung masih terkendala pada kualitas sumber daya manusia, dan dari ketersediaan anggaran. Alhasil, mereka kesulitan mengawal keterbukaan informasi publik di Provinsi Kepulauan Bangka Belitung.

Walaupun demikian, keterbatasan yang ada itu masih bisa diakomodasi. Hal ini antara lain karena-misalnya - jumlah sengketa informasi yang terjadi di Provinsi Bangka Belitung belum begitu banyak sehingga masih bisa diselesaikan secara tuntas dengan baik.
Dinas Komunikasi, Informatika, dan Statistik Kabupaten Bangka juga memiliki kendala dari segi sumber daya manusia. Hal tersebut diakui $\mathrm{M}$. Khadafi, S.Sos., Ketua Seksi Informasi Publik Dinas Komunikasi, Informatika, dan Statistik Kabupaten Bangka, yang mengatakan bahwa "dalam birokrasi sering terjadi perpindahan orang dari satu instansi ke instansi yang lain sehingga orang baru umumnya belum begitu memahami dengan masalah yang ada di tempat tersebut. Adapun dari sumber daya yang lain cukup baik meski belum terlalu optimal."

Pemerintah Desa Bukit Layang dan BPD Bukit Layang selaku badan publik desa dalam aspek ini, baik sumber daya manusia maupun sumber daya pendukung lain, secara umum dapat disimpulkan cukup baik. Hal ini juga didasarkan atas hasil wawancara dengan beberapa masyarakat Desa Bukit Layang dan pengamatan yang dilakukan penulis selama penelitian yang menunjukkan bahwa variabel ini dapat dikategorikan cukup baik.

Meskipun demikian, masih ada beberapa hal kecil yang harus ditingkatkan dan diperbaiki. Misalnya pembentukan Kelompok Informasi Masyarakat (KIM) Udang Satang Desa Bukit Layang yang masih pasif dikarenakan kelompok belum didukung penuh oleh Pemerintah Desa Bukit Layang, khususnya dalam hal anggaran. Padahal, keberadaan KIM memainkan peranan penting dalam upaya mewujudkan Desa Bukit Layang menjadi desa yang informatif.

\section{Disposisi}

Komisi Informasi Provinsi Kepulauan Bangka Belitung dan Dinas Komunikasi, Informatika, dan Statistik Kabupaten Bangka menunjukkan komitmen untuk melaksanakan sosialisasi 
keterbukaan informasi publik desa. Sosialisasi yang dilakukan memang masih belum begitu optimal dikarenakan keterbatasan anggaran khususnya. Walaupun demikian, mereka tetap berusaha menjalankan tugas dan fungsinya dengan baik.

Pemerintah Desa dan BPD juga menunjukkan sikap yang cukup baik, misalnya dengan membentuk Kelompok Informasi Masyarakat (KIM) dan memasang baliho/spanduk/banner APBDes untuk diketahui masyarakat desa sebagai perwujudan keterbukaan informasi publik di desa.

Namun, belum dibentuknya Pejabat Pengelola Informasi dan Dokumentasi (PPID) Desa dan peraturan desa tentang keterbukaan informasi publik desa juga menjadi persoalan yang cukup serius. Belum lagi tuntutan masyarakat yang ingin bentuk penyampaian informasi dilakukan dengan pendekatan yang bervariasi. Hal ini merupakan tantangan bagi Pemerintah Desa Bukit Layang dalam mewujudkan desa yang informatif.

\section{Struktur Birokrasi}

Dari aspek mekanisme, hal ini sudah berjalan sebagaimana mestinya. Misalnya, jika warga ingin meminta data atau informasi, mereka bisa menemui RT dan kepala dusun terlebih dahulu sebelum ke kantor desa. Cara yang kedua, mereka bisa langsung datang ke kantor Desa Bukit Layang. Pemerintah Desa akan meminta salinan (fotocopy) KTP yang bersangkutan dan surat tugas terkait keperluan dan pihak pemberi perintah. Tahap berikutnya, Kepala Urusan Tata Usaha dan Umum akan memberikan formulir yang harus diisi pemohon informasi publik. Jika memang informasi yang diminta bersifat terbuka dan tidak termasuk informasi dikecualikan, maka akan diberikan langsung kepada pemohon informasi publik.
Namun, jika informasi tersebut termasuk informasi yang dikecualikan, maka informasi yang diminta tidak dapat diberikan setelah menimbang konsekuensi yang timbul apabila informasi tersebut diberikan kepada pemohon.

Dalam hal koordinasi juga sudah berjalan. Pemerintah Desa Bukit Layang selalu berkoordinasi, baik dalam internal pemerintah desa maupun dengan pihak kecamatan atau kabupaten, jika terkait dengan pelaksanaan kebijakan keterbukaan informasi publik di desa. Akan tetapi, permasalahan seperti belum terbentuknya PPID Desa dan Peraturan Desa tentang keterbukaan informasi publik yang belum ditetapkan tentunya akan menjadi kendala administrasi dalam mewujudkan Desa Bukit Layang menjadi desa informatif di Kabupaten Bangka.

\section{KESIMPULAN DAN SARAN}

Berdasarkan hasil penelitian, dapat diambil kesimpulan sebagai berikut:

1. Variabel komunikasi dalam implementasi kebijakan keterbukaan informasi publik dalam mewujudkan desa informatif di Kabupaten Bangka (studi di Desa Bukit Layang Kecamatan Bakam) belum berjalan baik.

2. Variabel sumber daya dalam implementasi kebijakan keterbukaan informasi publik dalam mewujudkan desa informatif di Kabupaten Bangka (studi di Desa Bukit Layang Kecamatan Bakam) secara umum cukup baik.

3. Variabel disposisi atau sikap pelaksana maupun komitmen dalam implementasi kebijakan keterbukaan informasi publik dalam mewujudkan desa informatif di Kabupaten 
Bangka (studi di Desa Bukit Layang Kecamatan Bakam) sudah berjalan cukup baik.

4. Variabel struktur birokrasi dalam implementasi kebijakan keterbukaan informasi publik dalam mewujudkan desa informatif di Kabupaten Bangka (studi di Desa Bukit Layang Kecamatan Bakam) sudah berjalan cukup baik.

Berdasarkan kesimpulan di atas, penulis merekomendasikan beberapa saran sebagai berikut:

1. Pemerintah Desa Bukit Layang dan BPD Bukit Layang harus membuat dan menetapkan peraturan desa tentang keterbukaan informasi publik desa.

2. Kepala Desa Bukit Layang sebaiknya membentuk dan menetapkan Pejabat Pengelola Informasi dan Dokumentasi (PPID) Desa yang ditetapkan dengan surat keputusan kepala desa.

3. Pemerintah Desa Bukit Layang dan BPD Bukit Layang secara konsisten harus melakukan sosialisasi dan pertemuan dengan masyarakat desa membahas terkait dengan kegiatan, program maupun penggunaan dana desa dan realisasinya minimal satu bulan sekali.

4. Memanfaatkan situs Desa Bukit Layang yang telah difasilitasi oleh Dinas Komunikasi, Informatika, dan Statistik Kabupaten Bangka sebagai media penyaluran informasi di desa. Hal ini memudahkan masyarakat Desa Bukit Layang, khususnya, ketika ingin mendapatkan berbagai informasi yang dibutuhkan yang bisa diakses kapan pun dan di mana pun.

\section{DAFTAR PUSTAKA}

Batinggi, Achmad, dan Badu, Ahmad. (2014). Manajemen Pelayanan Umum. Jakarta:
Universitas Terbuka
Mulyadi, Deddy. (2016). Studi Kebijakan Publik dan Pelayanan Publik; Konsep dan Aplikasi Proses Kebijakan Publik Berbasis Analisis Bukti untuk Pelayanan Publik. Bandung: Alfabeta

Purwanto, E.A. dan Sulistyastuti, D.R. (2015). Implementasi Kebijakan Publik Konsep dan Aplikasinya di Indonesia. Yogyakarta: Gava Media

Sugiyono. (2017). Metode Penelitian Kuantitatif, Kualitatif, dan R\&D. Bandung: Alfabeta

Tahir, Arifin. (2015). Kebijakan Publik \& Transparansi Penyelenggaraan Pemerintah Daerah. Bandung: Alfabeta

Undang-Undang Dasar Republik Indonesia 1945

Undang-Undang Republik Indonesia Nomor 14 Tahun 2008 tentang Keterbukaan Informasi Publik

Peraturan Komisi Informasi Nomor 1 Tahun 2018 tentang Standar Layanan Informasi Publik Desa

Wahab, Solichin Abdul. (2017). Analisis Kebijakan dari Formulasi ke Penyusunan Model-Model Implementasi Kebijakan Publik. Jakarta: Bumi Aksara 